\title{
ERRATUM
}

M. Korn • W. Gfrörer · J. G. Filser · W. Kessler

\section{Styrene-7,8-oxide in blood of workers exposed to styrene}

Arch Toxicol (1994) 68: 524-527

The units on the ordinate "styrene-7,8-oxide in venous blood' in Fig. 1 A should be $[\mu \mathrm{g} / \mathrm{l}]$ instead of $[\mu \mathrm{g} / \mathrm{ml}]$; the units on the abscissa 'styrene in venous blood' in Fig. 1 B should be $[\mu \mathrm{g} / \mathrm{l}]$ instead of $[\mathrm{mg} / \mathrm{l}]$. 